DOI: $10.22363 / 2312-9220-2021-26-4-713-721$

УДК 32.019.5:316.4

Research article / Научная статья

\title{
Mediatization of Russian Companies in the Framework of Corporate Citizenship
}

\author{
Larisa V. Sharakhina ${ }^{(1)}$, Vera A. Achkasova ${ }^{(2)}$, \\ Liudmila V. Azarova ${ }^{(3)}$ \\ ${ }^{(1)(3)}$ St. Petersburg State Electrotechnical University "LETI", \\ 5 Prof. Popova St, St. Petersburg, 197376, Russian Federation \\ ${ }^{(2)}$ St. Petersburg State University, \\ VO, 1 Line, 26, St. Petersburg, 199004, Russian Federation
}

$\bowtie$ lvsharakhina@etu.ru

\begin{abstract}
The paper emphasis is made on corporate mediatization process conceptualization, which role is of high importance in Russia, because it influences sociopolitical situation on a legal basis, creates a form of business corporations' citizenship. The concept reveals a changing role of corporation in sociopolitical relations: due to encompassing corporate communication technologies it becomes necessary to meet communities' expectations, sociopolitical, socioeconomic, ecological issues. Thus, sociopolitical sphere mediatization in the context of complicating media discourse forms the situation when the modern business organization should become a corporate citizen giving a boost to societal development, wellbeing, confidence-building.
\end{abstract}

Keywords: strategic communication, corporate mediatization, corporate citizenship

Conflicts of interest. The authors declare that there is no conflict of interest.

Article history: submitted: March 10, 2021; accepted: June 1, 2021.

For citation: Sharakhina, L.V., Achkasova V.A., \& Azarova, L.V. (2021). Mediatization of Russian companies in the framework of corporate citizenship. RUDN Journal of Studies in Literature and Journalism, 26(4), 713-721. doi: 10.22363/2312-9220-2021-26-4-713-721 


\title{
Корпоративная медиатизация
}

как стратегический ресурс российских компаний:

на пути к корпоративному гражданству

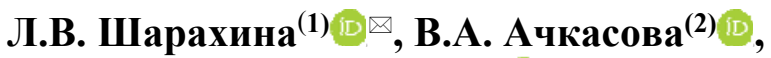 \\ Л.В. Азарова ${ }^{(3)}$ \\ ${ }^{(1)(3)}$ Санкт-Петербургский государственный \\ электротехнический университет «ЛЭТИ»,
}

Российская Федерачия, 197376, Санкт-Петербург, ул. Профессора Попова, 5

${ }^{(2)}$ Санкт-Петербургский государственный университет, Российская Федерачия, 199004, Санкт-Петербург, 1-я линия В.О., 26

lvsharakhina@etu.ru

\begin{abstract}
Аннотация. Придерживаясь социально-конструктивистского подхода, авторы рассматривают медиатизацию как новую форму социализации общества путем распространения инфокоммуникационных технологий, влияющих на всю систему общественных отношений. Основное внимание в статье уделяется процессу корпоративной медиатизации, который включает в себя изменение роли корпорации в системе социально-политических отношений. Корпоративная медиатизация стимулирует формирование ситуации, когда компания трансформируется в корпорацию-гражданина, заботящуюся о качестве жизни различных групп общественности. Итогом является эволюция концепции корпоративной социальной ответственности: современная бизнесоргани-зация - это член общества, который вносит существенный вклад в общественное развитие, благосостояние и формирование атмосферы доверия.
\end{abstract}

Ключевые слова: стратегические коммуникации, корпоративная медиатизация, корпоративное гражданство

Заявление о конфликте интересов. Авторы заявляют об отсутствии конфликта интересов.

История статьи: поступила в редакцию - 10 марта 2021 г.; принята к публикации - 1 июня 2021 г.

Для цитирования: Sharakhina L.V., Achkasova V.A., Azarova L.V. Mediatization of Russian companies in the framework of corporate citizenship // Вестник Российского университета дружбы народов. Серия: Литературоведение. Журналистика. 2021. Т. 26. № 4. C. 713-721. doi: 10.22363/2312-9220-2021-26-4-713-721

\section{Introduction}

The growing process of postindustrial society transformation involved business, governmental activities and their communication practices. The SaRSCOVID-19 outbreak in a case of well-established communication and IT-infrastructure forced reshaping of public relations towards symmetrical two-way model [1]. In such cases we are stating the deepening mediatization of social practices. 
We stick to socio-constructivist approach and review the mediatization as a new form of socialization by information and communications technologies, influencing the whole system of social and sociopolitical relations. An effective system of communication between media and non-media actors is observed as its result.

Russian companies with socially responsible practices based on their corporate and local governments' visions without much attention to public interests usually don't possess well established two-way communication frameworks with local publics. In cases of effective strategically based mutual communication of business and people of companies' presence territories, we esteem such companies as citizens, taking actions responding to local needs, creating the constellation of individual and corporate actors. Thus, we review a phenomenon of mediatized society supported and often created by corporate citizens.

The research purpose of the present article is to develop corporate mediatization phenomenon conceptualization illustrated by its influence on Russian companies' corporate responsibility programs.

Research methodology: complex analysis of empiric data (case study, 11 indepth interviews, content of the social programs concepts and social reporting of companies, the results of secondary research, etc.). The most important principle was a comprehensive analysis of empirical data based on social programs conducted by Russian corporations and the results of their implementation.

\section{Communicative figuration as the conceptual framework of corporate mediatization}

Development of corporate citizenship and corporate sustainability concepts, their implementation in the companies' activities formed the modern context of PR-specialists performance. The organization's corporate social responsibility (CSR) focus on sustainable development goals (The Global Compact Network) characterizes a new vision of strategic communications, its role in shaping public attitudes $[2,3]$; the business organization recognizes itself as a corporate citizen [4].

T. Knowlton notes: "the best corporate citizens are providing positive value to society and meeting or exceeding the expectations of their stakeholders" [5]. In the mid-2010s works focusing on the need to form a new model of socially oriented business (the corporate-citizen model) are emerging in Russia [6-8].

Digitalized interactive communication of postindustrial society involved different media and influences all spheres of social life [9]. While M. Castells focuses on cultural changes caused by mass media and information infrastructure, $\mathrm{N}$. Elias process sociology introduces a figurations concept as a "networks of individuals" [10. P. 15], "analytical tools that work across the levels of the micro, meso and macro and at the same time focus on the processes of constituting entities in-between the individual and society" [11. P. 10]. A. Hepp has developed 
it: "communicative figurations as patterns of processes of communicative interweaving that exist across various media and have a 'thematic framing' that orients communicative action" [11. P. 10].

SaRS-COVID-19 pandemic demonstrated unprecedented decisions made by governmental structures: countries borders were closed, people were locked. People and companies were confused awaiting decisions by states: what kind of assistance they can get to cope with negative situations. On the other hand, social structures, including nongovernmental and business sectors, with well-functioning communicative infrastructure with local citizens were able to deal with the issue. Such corporate citizens can be treated as communicative figurations [11].

In case of corporate citizens, according to Hepp A., Hasebrink U. [12], originated from $\mathrm{N}$. Elias, we observe specific constellation of actors as a structural basis; they provide to their audiences "thematic framing that serves as actionguiding topic"; organize "patterns of communicative practices" by a "specifically marked media ensemble". These communicative junctions of communicative figurations reveal a corporate mediatization processes phenomena: mediatized corporate citizens are able to establish larger, more stable social entities, blurring the barriers between individuals and business structures.

Moreover, global standards for sustainability reporting (GRI Standards) are reviewed as a feature of deep mediatization trend [13]: they structure the frameworks for reporting, the way of thinking about CSR and strategic communications: "When it comes to individual media, institualization refers to a stabilization of the patterns of communication and of expectations in the process: we know how a certain medium is typically used for communication, we communicate with the help of the medium in that way, and we expect others to do the same" [13. P. 8].

Therefore, corporate mediatization eliminates distinctions between individual and corporate levels and reveals itself in ideology of public affairs participation. Corporate citizens are oriented not only to economic efficiency, but to social interests, transform communicative space strategically, create mediatized world in which the company is perceived as a social actor and a corporate citizen. The structural basis of such figuration is represented by a corporate citizen, its stakeholders, involved in communication frameworks (thematic and media ensembles).

\section{Russian corporate citizens communication practices analysis}

Four leading Russian companies (GazpromNeft, Russian Railways, Norilsk Nickel, AFK Systema) were selected as cases, because of the following:

The scale of the activities of these companies.

Widely practiced social programs aimed to change the social climate in the areas of presence.

A mechanism for monitoring the results of social projects existence. 
UN Global Compact network and the Social Charter of Russian business participation.

In the course of the research the authors' attention was focused on the issues:

- the structural principles of social programs implemented by companies (areas of activity, coverage), making possible to review them as a constellations structural basis;

- the extent of such programs openness and transparency (primarily the social reporting is concerned), a media ensemble existence;

- the measurements of social projects implementation results (public attitudes monitoring and feedback);

- the use of Russian corporations strategic communications to form communicative practices thematic framing and patterns.

The results obtained determined the corporate mediatization features, its influence on the grounds on which the CSR of large Russian companies, as well as the role/functionality of strategic communications (PR).

The current stage of corporate citizenship development, when Russian business seeks to rethink the previous approaches, began in 2010: before this period CSR of business in Russia was understood as a variety of social investments, now corporate citizenship is perceived by management as corporate selfregulation, ensuring active compliance with the current legislation, socially responsible investment, adherence to ethical and international standards.

The effect of market incentives - the demands of investors, the corporate culture of responsible entrepreneurship - have been key reasons why Russian companies have adopted the practice of corporate citizenship [9]. The growing expectations of the local population were another important reason. We have to state that the level of trust in business of the Russian regions population is still low [14].

In these circumstances the Russian state support allowed companies to make the policy of corporate citizenship a tool for improving competitiveness, reducing transaction costs in the domestic market in the situation of a society mediatization. Hence, the CSR practice of companies with state capital becomes a kind of reference model, which can be used by other organizations.

"GazpromNeft" has been implementing the program "Hometowns" since 2012. The purpose of the program is to improve the quality of life in the territories of the company's presence. The social investment program of GazpromNeft is built into the company's development strategy, an integral element of which is the comprehensive development of the territories of its presence. But, according to experts, there are problems limiting the program's effectiveness: the regional public authorities are the key audience, on which the attention is focused; the main focus is not on the people satisfaction from CSR projects, but on measuring the association of them with "GazpromNeft".

Nevertheless, we observe the creation of corporate figurations on higher levels of hierarchy ("GazpromNeft" management, local and federal governments); 
media ensemble (owned corporate media, earned mass media) providing mostly one-way information pattern.

The scale of activity of "Russian Railways" (RZD Holding) caused the allRussian coverage of social programs: "We deal with pretty much everybody in Russia and sometimes with citizens of other countries". Among communication instruments used to demonstrate the company's contribution to community development are Mass Media publications and publications in journalistic text format in owned media. Of particular interest is measuring of implemented projects social impact effectiveness. The expert noted that RZD specialists measure 2 types of effectiveness: unmediated (quantitative data) and mediated ones, when the company creates real possibilities for people's personal fulfillment, territories development. The second approach demonstrates a wider constellation creation accompanied by well-developed media ensemble making possible to fix a develop-ped corporate mediatization phenomenon, but in a case of RZD we do not observe neither "thematic framing that serves as action-guiding topic" nor "patterns of communicative practices" by a "specifically marked media ensemble".

Markedly different approach to CSR has Sistema, a publicly-traded diversified holding in Russia and the CIS, one of the major private investors in real and Hi-Tech sectors. It established Sistema Charitable Foundation (operates in 81 regions) as a social investments, volunteer movement integrator with "a goal to unite competences of business, engineering communities, and non-profit organizations to solve definite socially important tasks by using innovative developments" [15]. Company emphasizes programs performance measuring.

Empirical data show Sistema has synchronized application of the whole communications mix implementing sustainable development social programs: event management, media relations, Internet activity, public reports. This Russian corporation is at the forefront of corporate citizenship formation, which demonstrates a mediatized corporate actor phenomenon.

Corporate citizenship is especially important for single-industry towns. The foundation of Norilsk Nickel's charitable activities is the large-scale program "World of new opportunities", launched in 2014, and aimed at supporting socially significant social initiatives to create favorable conditions and opportunities for sustainable development in the regions of activity; it includes three areas: partnership, innovation, development. Norilsk Nickel is guided in its activities by the principle of increasing transparency and information openness. The company publishes information on the official website and on corporate pages in social networks, holds press conferences, briefings and teleconferences. Cooperation with the media, including leading business publications of the country and the world, the world's largest news agencies and news channels, and social media has been built. The CSR reports provide several directions for evaluating the effectiveness of the company's social program, including measurements of staff involvement level, employee satisfaction, quality of corporate culture. 
The analysis of this case most clearly demonstrates the phenomena of corporate mediatization: company social programs implement one of the important principles of involving the public in the selection and implementation of programs and projects.

\section{Conclusion}

Corporate citizenship formation model in Russia is forced by mediatization:

- large companies began to use corporate citizenship as a tool for building transparent long-term mutually beneficial relations with stakeholders;

- the key reasons for the transition were market incentives - the requirements of investors and partners, the growing expectations of the local population and media.

Analysis of using strategic communications in CSR programs implementtation allows to fix corporate mediatization features:

- in the most of the companies studied, the communication strategy clearly fits into the corporate strategy. Companies aimed at achieving positive results in the regions of presence are paying more and more attention to the communicative component of their activities;

- integration is reflected in the establishment of special units for the planning and implementation of social programs to manage mediatized communication patterns;

- there's a transition from simple public awareness to its involvement in the selection and implementation of long-term social programs to create a more resistant social constellation.

The pilot study allows us to state the strengthening of strategic communication role in the formation of targeted long-term relations with stakeholders, leading to communicative figuration formation. In such figurations individual and corporate citizens become significant actors of the territory: it drives to a more sustainable development of the corporate actors, individual actors feel themselves more valuable, governmental structures are able to find support for socially important projects and initiatives.

Therefore, we conclude that corporate mediatization is a process, characterrized by:

- blurring the distance between individual and corporate levels;

- establishing a social entity of a higher resistance and complexity;

- transformation of people and business to public actors with a citizenship self-perception.

\section{References / Библиографический список}

[1] Grunig, J.E. (Ed.) (1992). Excellence in public relations and communication management. Hillsdale, NJ: Lawrence Erlbaum Associates. 
[2] Sarda, R., \& Pogutz, S. (2018). Corporate Sustainability in the 21st Century. Increasing the Resilience of Social-Ecological Systems. 1st Edition. New York: Routledge.

[3] Dutta, M.J. (2011). Communicating Social Change. New York: Routledge.

[4] Carroll, A.B. (1999). Corporate Social Responsibility: Evolution of a Definitional Construct. Business and Society, (38), 268-95. DOI:10.1177/000765039903800303

[5] Skroupa, C.P. (2018). What Does It Mean to Be a Strong Corporate Citizen? Forbes, 19 March. Retrieved March 25, 2021, from https:/www.forbes.com/sites/christopher skroupa/2018/03/19/what-does-it-mean-to-be-a-strong-corporate-citizen/\#3b600ed50ca 7

[6] Tulchinsky, G.L. (2012). Corporate social investments and social partnership: technologies and effectiveness measurement. SPb. (In Russ.)

Тульчинский Г.Л. Корпоративные социальные инвестиции и социальное партнерство: технологии и оценка эффективности: учеб. пособие. СПб., 2012.

[7] Blagov, Y.E. (2015). Corporate Social Responsibility. The evolution of Concept. St. Petersburg: HSM, St. Petersburg. (In Russ.)

Благов Ю.Е. Корпоративная социальная ответственность: эволюция концепции / Высшая школа менеджмента СПбГУ. СПб.: Изд-во «Высшая школа менеджмента», 2015.

[8] Kosorukov, A.A. (2017). Corporate citizenship as a form of government and business partnership in public area. Sociodynamics, (10), 45-58. (In Russ.)

Косоруков А.А. Корпоративное гражданство как форма социального партнерства государства и бизнеса в публичной сфере // Социодинамика. 2017. № 10. С. 45-58. doi: 10.25136/2409-7144.2017.10.21739

[9] Castells, M. (2009). The Rise of Network Society. DOI: 10.1002/9781444319514

[10] Elias, N. (1978). What is Sociology? London: Hutchinson.

[11] Hepp, A. (2013). The communicative figurations of mediatized worlds: Mediatization research in times of the "mediation of everything. European Journal of Communication, 28(6), 615-629. doi: 10.1177/0267323113501148

[12] Hepp, A., \& Hasebrink, U. (2014). Translocal communicative figurations. In Lundby, K. (Ed.): Media practice and everyday agency in Europe. Bremen.

[13] Hepp, A. (2019). Deep mediatization. London: Routledge. doi: 10.4324/9781351064903

[14] Institutional trust. (2018). Retrieved May 25, 2021, from https://www.levada.ru/2018/ 10/04/institutsionalnoe-doverie-4 (In Russ.)

Институциональное доверие. 2018. URL: https://www.levada.ru/2018/10/04/institu tsionalnoe-doverie-4

[15] Rack, I. (2018, May 24). CF "Sistema" will invest more than $200 \mathrm{mln}$. rubles in technological program. Retrieved March 25, 2021, from http:/www.sistema.ru/presscentr/press-relizy/detail/article/23359 (In Russ.)

Рак И. АФК “Система” инвестирует более 200 млн рублей в технологическую программу. URL: http://www.sistema.ru/press-centr/ press-relizy/detail/article/23359 (дата обращения: 25.03.2021).

\section{Bio notes:}

Larisa V. Sharakhina, PhD in Philosophy, Associate Professor, Head of PR Study Department, St. Petersburg State Electrotechnical University "LETI". ORCID: 0000-00020454-0448; e-mail: lvsharakhina@etu.ru

Vera A. Achkasova, Doctor of Politology, Professor, Head of PR in Politics and Public Administration, School of Journalism and Mass Communications, St. Petersburg State University. ORCID: 0000-0003-3396-9451; e-mail: v.achkasova@gmail.com 
Liudmila V. Azarova, PhD in Philology, Associate Professor, PR Study Department, St. Petersburg State Electrotechnical University "LETI". ORCID: 0000-0002-0682-4153; e-mail: azarovaludmilla@gmail.com

\section{Сведения об авторах:}

Шарахина Лариса Валентиновна, кандидат философских наук, доцент, заведующая кафедрой «Связи с общественностью» Санкт-Петербургского государственного электротехнического университета «ЛЭТИ». ORCID: 0000-0002-0454-0448; e-mail: lvshrakhina@etu.ru

Ачкасова Вера Алексеевна, доктор политических наук, профессор, заведующая кафедрой связей с общественностью в политике и государственном управлении Высшей школы журналистики и массовых коммуникаций Санкт-Петербургского государственного университета. ORCID: 0000-0003-3396-9451; e-mail: v.achkasova@gmail.com

Азарова Людмила Всеволодовна, кандидат филологических наук, доцент кафедры «Связи с общественностью» Санкт-Петербургского государственного электротехнического университета «ЛЭТИ». ORCID: 0000-0002-0682-4153; e-mail: azarovaludmilla@ gmail.com 